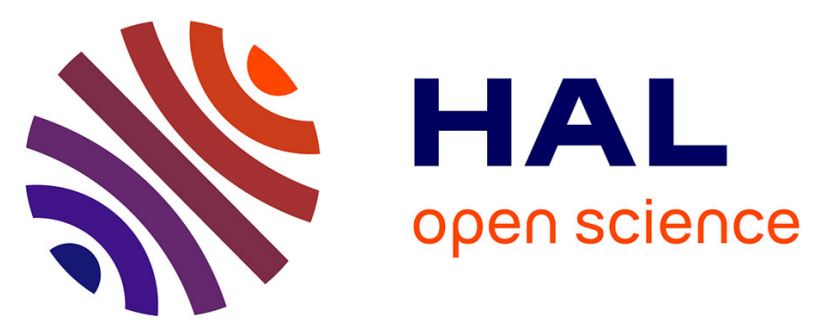

\title{
Factors Associated with Electronic Cigarette Use among Young Adults: The French "Trajectoires EpidéMiologiques en POpulation" (TEMPO) Cohort Study.
}

\author{
Hala Aljandaleh, Camille Bolze, Fabienne El-Khoury Lesueur, Maria
}

Melchior, Murielle Mary-Krause

\section{To cite this version:}

Hala Aljandaleh, Camille Bolze, Fabienne El-Khoury Lesueur, Maria Melchior, Murielle Mary-Krause. Factors Associated with Electronic Cigarette Use among Young Adults: The French "Trajectoires EpidéMiologiques en POpulation" (TEMPO) Cohort Study.. Substance Use and Misuse, 2020, 55 (6), pp.964-972. 10.1080/10826084.2020.1717534 . hal-02551079

\section{HAL Id: hal-02551079 \\ https://hal.sorbonne-universite.fr/hal-02551079}

Submitted on 22 Apr 2020

HAL is a multi-disciplinary open access archive for the deposit and dissemination of scientific research documents, whether they are published or not. The documents may come from teaching and research institutions in France or abroad, or from public or private research centers.
L'archive ouverte pluridisciplinaire HAL, est destinée au dépôt et à la diffusion de documents scientifiques de niveau recherche, publiés ou non, émanant des établissements d'enseignement et de recherche français ou étrangers, des laboratoires publics ou privés. 
Factors associated with electronic cigarette use among young adults:

\section{The French "Trajectoires EpidéMiologiques en}

\section{POpulation" (TEMPO) cohort study}

Running title: Factors associated with electronic cigarette use among young adults

Hala Aljandaleha, Camille Bolzea, Fabienne El-Khoury Lesueura, Maria Melchiora, Murielle MaryKrause ${ }^{a}$

a. Sorbonne Université, INSERM, Institut Pierre Louis d’Epidémiologie et de Santé Publique (IPLESP), Equipe de Recherche en Epidémiologie Sociale (ERES), F75012, Paris, France.

Corresponding author

Murielle Mary-Krause

INSERM U1136

Faculté de Médecine St Antoine

27 rue de Chaligny

75571 Paris Cedex 12

France

murielle.mary-krause@iplesp.upmc.fr

ORCID : https://orcid.org/0000-0002-8156-1007

Abstract: 229 words / 250

Manuscript: 4162 words / 5000

Tables - Figures: 2

Supplementary Data: 1 figure 
Factors associated with electronic cigarette use among young adults:

\section{The French "Trajectoires EpidéMiologiques en}

\section{POpulation" (TEMPO) cohort study}

Running title: Factors associated with electronic cigarette use among young adults

Hala Aljandaleha, Camille Bolzea, Fabienne El-Khoury Lesueura, Maria Melchiora, Murielle MaryKrause $^{a}$

a. Sorbonne Université, INSERM, Institut Pierre Louis d'Epidémiologie et de Santé Publique (IPLESP), Equipe de Recherche en Epidémiologie Sociale (ERES), F75012, Paris, France.

Corresponding author

Murielle Mary-Krause

INSERM U1136

Faculté de Médecine St Antoine

27 rue de Chaligny

75571 Paris Cedex 12

France

murielle.mary-krause@iplesp.upmc.fr

ORCID : https://orcid.org/0000-0002-8156-1007

Abstract: 229 words / 250

Manuscript: 4162 words / 5000

Tables - Figures: 2

Supplementary Data: 1 figure 


\section{ABSTRACT}

\section{Background}

Electronic cigarettes (e-cigarettes) are sold in France since 2010 and have rapidly become popular. However, factors associated with e-cigarette use among young adults are not well known.

\section{Methods}

We used data from the 2015 French TEMPO community based cohort study, restricted to current and former smokers with data on e-cigarette use ( $n=368$ adults, 23-41 years). Participants completed a self-administered questionnaire including information on family status, educational attainment, occupation and type of work contract, health problems, alcohol and cannabis use, electronic cigarette use, as well as perceptions of e-cigarettes. Use of traditional tobacco was assessed in 2011 and 2015. Data were analyzed using logistic regression models.

\section{Results}

Among current and former smokers, 26.9\% reported lifetime e-cigarettes use and 15.2\% current use. Factors associated with lifetime use were: low socioeconomic position $(\mathrm{OR}=2.2 ; 95 \%$ $\mathrm{Cl}=1.2-4.2$ ), traditional cigarette use (OR associated with smoking in 2011 and 2015=13.1; 95\% $\mathrm{Cl}=5.2-32.6)$ and positive perceptions of e-cigarettes $(\mathrm{OR}=4.4 ; 95 \% \mathrm{Cl}=2.4-8.1)$ as well as asthma $(\mathrm{OR}=2.1 ; 95 \% \mathrm{Cl}=0.9-4.9)$ and overweight/obesity $(\mathrm{OR}=2.5,95 \% \mathrm{Cl}=0.9-6.9)$. Factors associated with current use were traditional cigarette smoking (OR associated with smoking in 2011 and $2015=3.9 ; 95 \% \mathrm{Cl}=1.3-12.2)$ and positive perceptions of e-cigarettes $(\mathrm{OR}=4.4 ; 95 \% \mathrm{Cl}=2.3-8.4)$.

\section{Conclusions}

Young adults who use e-cigarettes tend to persist in smoking traditional cigarettes. The conditions under which e-cigarette use can help individuals quit traditional tobacco products remain to be elucidated.

KEYWORDS: Electronic cigarette; Young adults; Smoking; Associated factors; cohort; France 


\section{Introduction}

Since they were first marketed, electronic cigarette (e-cigarette) use has spread around the world (Greenhill, Dawkins, Notley, Finn, \& Turney, 2016), generating questions regarding the appropriate level of regulation and public health implications. Awareness of e-cigarettes and ecigarette experimentation have doubled both among adults and adolescents in many countries since 2008 (Grana, Benowitz, \& Glantz, 2014). E-cigarette use has increased over time, especially among smokers to reduce their consumption of traditional tobacco products or to quit smoking (Queloz \& Etter, 2019). Nonetheless, a recent study showed that e-cigarettes may have a higher addictive potential than smoked cigarettes (Jankowski et al., 2019).

In France, e-cigarettes have been marketed since 2010 and awareness of e-cigarette rapidly increased (Andler et al., 2016; European Union, 2012). According to the results of a national health survey conducted in 2016 among 15-75 year olds (Pasquereau, Gautier, et al., 2017), $22.3 \%$ of women have ever tried e-cigarettes versus $26.7 \%$ of men. The same sex difference is observed amongst daily users (1.9\% of women versus 3.0\% of men) (Pasquereau, Gautier, et al., 2017). Regarding age, $44.6 \%$ of young people aged 15 to 24 years have ever tried e-cigarettes versus $5.4 \%$ of the $65-75$ year olds, although age differences in current use are less marked (Andler et al., 2016; Pasquereau, Gautier, et al., 2017). In France, although the rate of ecigarette experimentation has not changed over time, the prevalence of current e-cigarette use decreased between 2014 and 2016 (5.9\% vs 3.3\%, respectively) as well as the prevalence of daily use $(2.9 \%$ to $2.5 \%)$, particularly among $15-24$ year olds $(2.1 \%$ to $1.2 \%)$ (Pasquereau, Gautier, et al., 2017). Although the prevalence of daily-use is not particularly high among adolescents and young adults, experimentation is frequent and it is important to identify the factors associated with different uses, particularly in the context of recent cases of acute lung injury potentially associated with vaping reported in the US (Centers for Disease Control and Prevention [CDC], 2019).

Prior studies show that factors associated with the use of e-cigarettes include male sex, older age and use of traditional tobacco products, as well as low educational level, income or occupational grade (Christensen, Welsh, \& Faseru, 2014; Lermenier \& Palle, 2014; Pasquereau, Gautier, et al., 2017; Reid, Rynard, Czoli, \& Hammond, 2015; Rutten et al., 2015; Spilka, Le Nezet, Ngantcha, \& Beck, 2015). A recent study showed an association between e-cigarette use 
and a variety of mental health and drug-related problems (Grant, Lust, Fridberg, King, \& Samuel, 2019). However, these studies have limitations. Most were cross-sectional, making it difficult to ascertain the role of e-cigarettes in the context of long-term use of other tobacco products. This study design does not inform about the temporal sequence of events and cannot be used to infer causality. Moreover, most prior studies investigated prevalence trends in ecigarette use (Andler et al., 2018; Chen et al., 2019; Oakly, Edwards \& Martin, 2019; U.S. Department of Health and Human Services, 2016, Chapter 2), perceptions (Brikmanis, Petersen \& Doran, 2017; Choi \& Forster, 2014), or transitions between e-cigarette use and tobacco smoking (Soneij et al., 2017) among young adults. However, less is known about factors associated with e-cigarette use specifically among young adults, even though this age group is characterized by high levels of cigarette smoking (Andler et al., 2016), and a high number of smoking cessation attempts (Bancej, O’Loughlin, Platt, Paradis, \& Gervais, 2007; Tworek et al., 2014), so a possible use of e-cigarettes to stop smoking. Lifestyle changes at that age (for example, parenthood) can lead to attempts to quit smoking and can be associated with an increase in e-cigarette use (Khati et al., 2015). Young adults who quit smoking have similar life expectancy to non-smokers, and encouraging reductions in tobacco use in this group is a public health priority (Doll, Peto, Boreham, \& Sutherland, 2004).

In the present study, we use data from the French TEMPO cohort (Trajectoires EpidéMiologiques en POpulation, “population-based epidemiological trajectories”), specifically designed to study young adults' health, to examine factors that are related to e-cigarette use. Specifically, we examine demographic, socio-economic, health, psychological and behavioral characteristics associated with lifetime and current e-cigarette use.

\section{Methods}

\section{Design (Supplementary Figure 1)}

The TEMPO study, based in France, was set up in 2009 to follow-up young adults aged 22-35 years who had taken part in a study of children's psychological problems in 1991, whose parents participated in the GAZEL cohort study (Redonnet, Chollet, Fombonne, Bowes, \& Melchior, 
2012). The Gazel cohort was launched in 1989 among employees of a large public sector utility company in France, to study long-term adult health.

In 2009, a self-administered questionnaire was sent to parents of youths who had taken part in the 1991 study, asking them to forward the TEMPO questionnaire to their son/daughter. A total of 1103 young adults aged 22 to 35 years old responded to the study questionnaire. Nonparticipants were more likely to come from divorced families and to have a low socio-economic position. In 2011, the TEMPO cohort was expanded to include all offspring of GAZEL study participants' aged from 18 to 25 years (one child per family). The 2011 TEMPO study was completed by 1214 participants, via telephone interview $(80 \%)$ or online questionnaire $(20 \%)$. In 2015, 786 people responded to the TEMPO study questionnaire (64.7\% response rate).

Based on data collected in 2011, the 2015 TEMPO study participants and non-participants have the same characteristics, except that 2015 study participants were more likely to come from an intermediate or high socio-economic position than non-participants $(67.8 \%$ vs $57.5 \%, p=0.0007)$, they were less likely to suffer from migraine $(15.9 \%$ vs $20.5 \%, p=0.0466)$ and to be regular smokers $(19.5 \%$ vs $27.4 \%, p=0.0008)$.

In comparison with the general population of young adults in France, TEMPO participants have more favorable socio-economic circumstances (e.g. unemployment rate of $4.5 \%$ vs. $8.3 \%$ ) (Institut national de la statistique et des études économiques [Insee], 2011).

The TEMPO cohort was approved by the French national committee for data protection (CNIL: Commission Nationale Informatique et Liberté).

\section{Sampling}

Because only two non-smokers in our study used an e-cigarette, data were restricted to smokers and former smokers of traditional cigarettes. The population restriction was based on the 2015 question about tobacco use: «Are you currently a regular ( $\geq$ one cigarette per day), an occasional (< one cigarette per day), or a former smoker or a non smoker?». Among the 786 TEMPO participants who completed the 2015 questionnaire, 12 had missing smoking data and 396 
were non-smokers. Among the 378 remaining participants who smoked tobacco daily, occasionally or were former smokers, 10 had no data on e-cigarette use. A total of 368 participants were included in the present analysis.

\section{Study outcomes}

The questionnaire included 4 questions about e-cigarette use. First, participants were asked if they smoked cigarettes at the time of the questionnaire or formerly and if they used an ecigarette to stop or reduce their tobacco consumption (No, Yes to stop smoking, Yes to reduce tobacco consumption). Second, participants who responded positively were further asked how long they used an e-cigarette for (< 7 days, [7 days - 1 month[, [1 month - 3 months[, [3 months - 6 months[, [6 months - 9 months[, [9 months - 12 months[, $\geq 12$ months). Third, all participants were asked: «Do you currently use an e-cigarette?» (Never, Sometimes, Every day or almost). Fourth, those who responded ever using an e-cigarette were asked «When was the last time you used an e-cigarette (even one puff)?» (< 24 hours, [24 hours - 7 days[, [7 days - 1 month[, [1 month - 3 months[, [3 months - 6 months[, [6 months - 9 months[, [9 months - 12 months[, $\geq 12$ months).

To define lifetime e-cigarette use we combined the two questions about e-cigarette use to stop smoking or to reduce tobacco consumption and about current e-cigarette use, whereas only these last question was used to define current e-cigarette use. For lifetime e-cigarette use, it is necessary to combine both questions because current e-cigarette use refers to behaviour at the time of the study. Therefore «never» means «currently no» and not «never in life» for smokers or former smokers who could have used an e-cigarette in the past. Ever use was defined by combining e-cigarette use to stop smoking or to reduce tobacco consumption and current use (sometimes and every day or almost every day). Current use was defined as e-cigarette use « sometimes » or « every day or almost every day ».

\section{Characteristics potentially associated with e-cigarette use}


All variables included in the analyses were reported in 2015, except participants' smoking status which was reported in 2011 and 2015 and cannabis and alcohol use which were reported in 2011.

\section{Demographic characteristics}

Demographic characteristics included sex (male vs. female), age (23-35 vs. 36-42 years), living with a partner (yes vs. no), parental status (no children, a child aged $\leq$ one year and have a child aged >one year, half of women who obtain smoking cessation during pregnancy relapse in the first year postpartum) (Allen et al., 2019; Rockhill et al., 2016) which were assessed in 2015, adverse life events in the preceding 12 months (for example: separation from the spouse or death of a close person; yes vs. no), the experience of physical violence in the preceding 12 months (yes vs. no) and the experience of psychological violence in the preceding 12 months (yes vs. no) which were assessed in 2011.

\section{Socioeconomic position (SEP)}

SEP was determined by combining participants' educational level (< vs. $\geq$ Bachelor's degree) and occupational category (clerk or manual worker vs. farmer, chop owner, head of company, administrative assistant, technician, manager, engineer, physician or artist) assessed in 2015, unemployment in the preceding year ( $\leq$ vs. > 6 months) and type of contract (stable vs precarious) assessed in 2011 and 2015. Each of these variables was coded 0 or 1; then all 4 were summed. The SEP distribution was dichotomized according to the lower quartile (low vs. intermediate/high SEP) (Melchior et al., 2007; Redonnet et al., 2012).

\section{Health characteristics}

Self-rated health was measured in 2015 using the question "How do you rate your health in general?", with a 7-pont Likert scale ranging from "very good" to "very bad". Responses were dichotomized as: good (1-4) or not good (5-7). Obesity was defined based on self-reported weight and height (Body Mass Index (BMI) $\geq 30 \mathrm{~kg} \cdot \mathrm{m}^{2}$ ) (World Health Organization [WHO], 2018). Self-reported diagnoses in 2015 of chronic diseases (asthma, depression, migraine, cardiovascular disease, diabetes, obesity, chronic digestive diseases, cancer and musculoskeletal disorders) were combined to ascertain the presence of a chronic disease (yes vs. no). 


\section{Psychoactive products consumption}

Regular smoking of traditional cigarettes ( $\geq 1$ cigarette per day in the preceding 12 months) was ascertained in 2011 and 2015 (Redonnet et al., 2012). Participants were categorized as regular smokers a) in 2011 and 2015, b) neither in 2011 nor in 2015 (ex-smokers), c) only in 2011, d) only in 2015. Cannabis use was measured using the question "How many times have you used cannabis in the preceding 12 months?"(0 vs. $\geq 1)$ (Redonnet et al., 2012). Alcohol abuse was assessed by the French version of the AUDIT (Alcohol Use Disorders IdenTification) (Babor, Higgins-Biddle, Saunders, \& Monteiro, 2001), a 10-item questionnaire validated by the World Health Organization (WHO) which makes it possible to identify alcohol abuse (yes vs. no).

\section{Perceptions of e-cigarette use}

Perceptions of e-cigarettes were ascertained in 2015 via a score based on the level of agreement with 3 assertions: "E-cigarettes can help quit smoking", "E-cigarettes are less harmful than traditional cigarettes containing tobacco", "E-cigarettes trigger less dependence than traditional cigarettes containing tobacco". Possible responses were coded on a Likert scale ranging from "does not agree at all" (1) to "totally agrees" (5). We dichotomized the response to each assertion (1-3 coded 0$)$ vs. (4-5 coded 1). The assertion 3, labeled « neither agree nor disagree », was included with the non positive perception in order not to overestimate the positive perception. Then, we summed the responses to these three assertions to build an overall score with a Cronbach's alpha of $\mathbf{0 . 7 8}$, indicating good internal reliability (Tavakol \& Dennick, 2011). The final perception score of e-cigarettes was dichotomized according to the score value, considered as non positive if equal to 0 or 1 and positive if equal to 2 or 3.

\section{Data Analyses}

We estimated the prevalence of lifetime and current e-cigarette use, and then investigated factors associated with e-cigarette use with multivariate logistic regression models. Variables associated with lifetime and current e-cigarette use, with a $\mathrm{p}$ value $\leq 0.20$ in bivariate logistic regression models, were included in multivariate logistic regression models. As we do not know whether perceptions precede use or vice versa, we performed a sensitivity analysis with a 
multivariate logistic regression model without the perception of e-cigarettes covariate. All missing data for the explanatory variables were imputed using multiple imputations by Fully Conditional Specification (FCS) (van Buuren, 2007). Percentages of missing values across covariates varied from to $1 \% 12 \%$.

The average number of traditional cigarettes smoked per day was estimated among regular smokers for each year and was compared between 2011 and 2015 with t-test among lifetime ecigarette users, current e-cigarette users and never users. Difference between groups was tested using Anova test.

Data were analyzed using SAS 9.4 software (SAS Institute, 2013).

\section{Results}

\section{Characteristics of lifetime or current e-cigarette use (Table 1)}

The studied population $(n=368)$ comprises $26.9 \%$ lifetime users of e-cigarettes and $15.2 \%$ current users. Among this population, two thirds were women, almost half aged of 23 to 35 years, one fifth had a child aged $\leq 1$ year old, one third had a low socio-economic position, $22 \%$ had a chronic disease and roughly one-third were smokers both in 2011 and in 2015. Compared to nonusers, lifetime and current e-cigarette users were more likely to live alone, smoke traditional cigarettes and have positive perceptions of e-cigarettes. In addition, lifetime e-cigarette users were more likely to have asthma and to use cannabis, this last being near the significant for current e-cigarette users.

\section{Risk factors of lifetime or current e-cigarette use (Table 2)}

After adjustment in multivariate analysis, lifetime e-cigarette use was associated with low socioeconomic position. Compared to former smokers, smokers of traditional cigarettes both in 2011 and in 2015 were more likely to use e-cigarettes, as were smokers of traditional cigarettes in 2011 but not in 2015 and smokers of traditional cigarettes in 2015 but not in 2011. 
Unsurprisingly, a positive perception of e-cigarettes was also associated with lifetime use. Lifetime e-cigarette use did not seem associated with health, but an association is not far from statistical significance for asthma (OR=2.1; 95\% $\mathrm{Cl}=0.9-4.9)$ and overweight/obesity $(\mathrm{OR}=2.5,95 \%$ $\mathrm{Cl}=0.9-6.9)$.

After adjusting for the same confounding factors, current e-cigarette use was only associated with tobacco smoking and the perception of e-cigarettes.

Same results were found when perception of e-cigarette was not included in different models (data not shown).

\section{Changes in patterns of traditional cigarette smoking over time}

Lifetime and never e-cigarette users differs significantly in terms of current traditional tobacco use across all study years ( $p=0.005$ in 2011 and $p=0.001$ in 2015) with no statistically significance differences between lifetime and current e-cigarette users $(p>0.20)$. Furthermore, we found that lifetime and current e-cigarette users did not reduce their consumption of traditional cigarettes between 2011 and 2015: 11.5 (standard deviation (sd) 6.6) cigarettes and 11.2 (sd 5.5) ( $p=0.78)$ among lifetime e-cigarette users, as compared with 9.6 (sd 6.0) and 9.8 (sd 4.9) $(p=0.88)$ among current users and 8.5 (sd 5.1) and 7.9 (sd 5.7) ( $p=0.55)$ among never e-cigarette users.

\section{Discussion}

Studying a sample of young adults, we found that lifetime e-cigarette use is associated with low socioeconomic position, traditional cigarette smoking and positive perception of e-cigarettes as well as asthma and obesity which are close to significance. In particular, persistent smokers are more likely to use e-cigarettes than former smokers. The only factors associated with current ecigarette use in our study are traditional cigarette smoking and positive perception of ecigarettes. 
Our findings highlight the high levels of concurrent e-cigarette and traditional tobacco use among young adults. It may be that e-cigarettes do not help smokers who previously used ecigarettes stop smoking, suggesting the inefficiency of this device with regard to smoking cessation. To establish the relationship between the use of e-cigarettes and traditional tobacco products, longitudinal studies that follow individuals over the long-term are needed.

\section{Limitations and strengths}

Our study has several limitations. First, TEMPO study participants are selected as offspring of participants of a longitudinal follow-up who at study baseline were employed in a large energy company and accepted to take part in an epidemiological cohort study. Therefore, our sample is not representative of the general population of young adults, and in particular TEMPO participants had higher socio-economic position and less likely to report tobacco smoking (Guignard et al., 2015). Thus, the association between low socioeconomic position and ecigarette use may be stronger than we report. Similarly, the rate of lifetime e-cigarette use was $13 \%$ in our study as compared with $32 \%$ in the general French population aged of 25 to 44 years (Andler et al., 2016). This probably does not have implications regarding the associations we observe between participants' characteristics and e-cigarette use, although associations between tobacco smoking and e-cigarette use may actually be stronger in the general population. Second, due to small numbers of e-cigarette users, we may have lacked statistical power to study some rare phenomena (for example the role of health problems). Nevertheless, health problems are not a direct motivation of smoking cessation in young adults, as opposed to older persons (Gallus et al., 2013). Third, e-cigarette use data were self-reported, which can generate recall bias. However, there is no reason to believe that this bias is systematic as there is no particular stigma associated with e-cigarette use and the phenomenon is quite recent. To our knowledge, self-reported questionnaires are the most valid type of measurement to assess ecigarette use (Foulds et al., 2015).

Our study has several strengths that offset the previously cited limitations. First, our data are longitudinal, which gave us the opportunity to measure tobacco use at two time points, before and after the dissemination of e-cigarettes and to take into account negative life events, 
physical and psychological violence, depression assessed in childhood. Second, we studied a community of young adults, who are often difficult to survey yet have high levels of tobacco and e-cigarette use (Pasquereau, Gautier et al., 2017). Third, longitudinal measures of family and juvenile characteristics were obtained independently of participants' reports of substance use. Fourth, we took into account several psychoactive substances in a single population, making it possible to study the potential associations. Fifth, our study is conducted in France where levels of tobacco use are among the highest in the world (Ng et al., 2014), making it an interesting setting to examine associated factors and long-term outcomes.

\section{Comparison with other studies}

We have only two non-smokers in our study who ever used e-cigarettes that is $0.3 \%$, which is comparable to prevalence rates reported in previous studies (Hajek, Etter, Benowitz, Eissenberg, \& Mc Robbie, 2014). Thus, studying the general population or smokers and former smokers are equivalent.

In bivariate analyses, lifetime e-cigarette use was highest in participants who were single, although this association was no longer statistically significant in the multivariate regression model. Two US studies explored the role of demographic characteristics: one found no association with current e-cigarette use (Rutten et al., 2015), while another one revealed that lifetime e-cigarette users are more likely to live with a partner than non-users (Christensen et al., 2014). This difference in results could be explained by differences between the populations studied: Christensen's study did not control for covariates and was carried out in a rural region of the United States (Christensen et al., 2014), whereas Rutten et al. (2015) carried their investigation in a more diverse population.

In our study, low socioeconomic position was associated with lifetime but not current e-cigarette use, which differs from the results obtained in a national French health survey conducted among adults (Andler et al., 2016). This could reflect lack of statistical power in our study. E-cigarettes could also be particularly attractive to persons with low socioeconomic position who have the highest levels of traditional tobacco use and may be particularly interested in reducing the costs 
associated with their smoking habit. In the long-term, e-cigarettes are cheaper than traditional cigarettes in France (Le Monde, 2014). Indeed, in France, a pack of cigarettes costs 6.30 to 8.30 euros (Official Journal of the French Republic, 2019) that is, for a smoker of one pack per day, 192 to 253 euros per month. E-cigarettes cost 20 to 50 euros, and $10 \mathrm{ml}$ of e-liquid cost an additional then 5-7 euros. A cartridge equivalent to one pack/day (Calumette, 2019) amounts to an expense of 15-34 euros per month.

Close to the significance, our study showed that having asthma is probably a risk factor of lifetime but not current e-cigarette use. This is consistent with prior research (Choi \& Bernat, 2016), although some studies have showed that "current" e-cigarette users also tend to be more often asthmatic than non-users (Cho \& Paik, 2016). In addition, we found that overweight/ obesity is associated with lifetime e-cigarette use, which may reflect overall deleterious health habits as well as weight gain following smoking cessation. Thus health reasons, which are known to be involved in tobacco cessation among older adults, also appear to influence the likelihood of e-cigarette experimentation in young adults; however, these health characteristics were not associated with current e-cigarette use.

We found that the use of traditional tobacco is related to lifetime and current use of ecigarettes, as has been observed in several studies (Andler et al., 2016; Christensen et al., 2014; Lermenier \& Palle, 2014; Li, Newcombe, \& Walton, 2015; Reid et al., 2015). A French study suggested the possibility that current e-cigarette use influences the reduction of traditional tobacco use over a follow-up period of 6 months (Pasquereau, Guignard, Andler, \& NguyenThanh, 2017). Another study, with a follow-up period of 12 months in a population of current ecigarette users, found that the rates of relapse to smoking were low in former smokers and the rates of cessation high in current smokers (Etter, 2018). However, this study was conducted among a selected sample of vapers, and long-term patterns of e-cigarette and traditional tobacco use should be examined in representative samples (Etter, 2018). In our study, current ecigarette use was associated with disrupted patterns of traditional tobacco use, which is consistent with the hypothesis that individuals who use e-cigarettes attempt to quit smoking. Moreover, the number of cigarettes per day is higher among lifetime e-cigarette users than among never e-cigarette users indicating attempts to quit smoking among e-cigarette users. 
However, these attempts are not always successful, since the majority of e-cigarette users in our study continued to use traditional tobacco without even reducing their consumption level. High levels of concurrent dual use of e-cigarettes and traditional tobacco have previously been observed among adults and youths. A recent Italian study showed that individuals re(starting) smoking after using e-cigarettes outnumber those who stop smoking after using e-cigarettes (Liu et al., 2019). The prevalence of e-cigarette use is higher among current smokers than among former smokers or smokers (Hedman et al., 2018).

As expected, we found that a positive perception of e-cigarettes is related to lifetime and current e-cigarette use. We do not know whether perceptions precede use or vice versa, nevertheless it may be that a positive view of the product is a first step towards regular use. These results were also observed in a population of adolescents from Minnesota (Choi \& Forster, 2014). As with any psychoactive product, consumers do not necessarily have an objective view of the associated harm. Moreover, the idea that e-cigarettes are less harmful than traditional tobacco products is widespread, including among physicians. It is important to note that neither long-term data on the risks associated with e-cigarette use, nor trajectories of use are currently known (Deville \& Charlier, 2017). Nevertheless, even if daily e-cigarette users among college students reported greater positive perceptions and benefits of e-cigarette as compared to tobacco than non-daily users, daily users also perceive greater health risks of the e-cigarette than non-daily users (Mayorga, Garey, \& Zvolensky, 2019). As consumer perceptions of the risks and benefits of e-cigarettes are heavily influences by marketing and media reports (Grana et al., 2014), adequate prevention campaigns counteracting these mechanisms are necessary

\section{Conclusions}

The use of e-cigarettes is mainly related to the use of traditional tobacco products, socioeconomic factors, health and a positive perception of e-cigarettes. In young adults the likelihood of using e-cigarettes is less strongly associated with health problems than among older persons. Importantly, while e-cigarettes appear to be used in an attempt to quit smoking, we found no evidence of an actual decrease in smoking levels among e-cigarette users. Additional 
longitudinal studies are needed to explore smokers' motivations to use regularly and the role of e-cigarettes with regard to tobacco consumption and long-term health. 


\section{Acknowledgements}

We thank TEMPO and GAZEL study participants who provided data for this project, as well as the GAZEL cohort study team for assistance in data collection tasks.

\section{Disclosure statement}

All authors have no conflicts of interest to declare.

\section{Funding}

This work was supported by the French National Research Agency (ANR); French Institute for Public Health Research-IReSP (TGIR Cohortes); the French Inter-departmental Mission for the Fight against Drugs and Drug Addiction (MILDeCA); the French Institute of Cancer (INCa); and the Pfizer Foundation. 


\section{References}

Allen AM, Jung AM, Lemieux AM, Alexander AC, Allen SS, Ward KD, \& al'Absi M (2019). Stressful life events are associated with perinatal cigarette smoking. Prev Med, 118, 264-271. doi: 10.1016/j.ypmed.2018.11.012

Andler R, Guignard R, Wilquin JL, Beck F, Richard JB, \& Nguyen-Thanh V (2016). Electronic cigarette use in France in 2014. Int J Public Health, 61(2), 159-165. doi: 10.1007/ s00038-015-0773-9

Andler R, Guignard R, Spilka S, Le Nézet O, Pasquereau A, Richard JB, \& Nguyen-Thanh V (2018). Consommation de tabac et usage de cigarette électronique en France [Smoking and vaping in France]. Rev Mal Respir, 35(6), 673-685. doi: 10.1016/j.rmr.2018.01.008

Babor TF, Higgins-Biddle JC, Saunders JB, \& Monteiro MG (2001). AUDIT: The Alcohol Use Disorders Identification. Guidelines for use in primary care. World Health Organization, Department of mental health and substance dependence. Geneva: World Health Organization.

Bancej C, O’Loughlin J, Platt RW, Paradis G, \& Gervais A (2007). Smoking cessation attempts among adolescent smokers: a systematic review of prevalence studies. Tob Control, 16(6), e8. doi: 10.1136/tc.2006.018853

Brikmanis K, Petersen A, \& Doran N (2017). E-cigarette use, perceptions, and cigarette smoking intentions in a community sample of young adult nondaily cigarette smokers. Psychot Addict Behav, 31(3), 336-342. doi: 10.1037/adb0000257

Calumette (2019). Clopes et vapes: une comparaison difficilement quantifiable [Smoking and vaping: a comparison that is difficult to quantify]. Retrieved from https: // www.calumette.com/guide/e-liquide/c166.php

Centers for Disease Control and Prevention [CDC] (2019). Health advisory: Severe pulmonary disease associated with using e-cigarette products. Atlanta, US Department of Health and Human services, CDC. Retrieved from https://emergency.cdc.gov/han/han00421.asp

Chen YL, Wu SC, Chen YT, Hsiao PC, Yu YH, Ting TT, Chen CY, Tu YK, Huang JH, Yang HJ, Li CY, Strong C, Yen CF, Yen CF, \& Chen WJ (2109). E-cigarette use in a country with prevalent tobacco smoking: a population-based study in Taiwan. J Epidemiol, 29(4), 155-163. doi: 10.2188/jea.JE20170300 
Cho JH, \& Paik SY (2016). Association between Electronic Cigarette Use and Asthma among High School Students in South Korea. PLoS One, 11(3): e0151022. doi: 10.1371/journal.pone. 0151022

Choi K, \& Forster JL (2014). Beliefs and Experimentation with Electronic Cigarettes: A Prospective Analysis among young adults. Am J Prev Med, 46(2), 175-178, doi: 10.1016/ j.amepre.2013.10.007

Choi K, \& Bernat D (2016). E-Cigarette Use Among Florida Youth With and Without Asthma. Am J Prev Med, 51(4), 446-453. doi: 10.1016/j.amepre.2016.03.010

Christensen T, Welsh E, \& Faseru B (2014). Profile of e-cigarette use and its relationship with cigarette quit attempts and abstinence in Kansas adults. Prev Med; 69, 90-94. doi: 10.1016/j.ypmed.2014.09.005

Deville M, \& Charlier C (2017). Electronic cigarette: state of the science about toxicological aspects. Rev Med Liege, 72(1), 20-24. PMID: 28387073

Doll R, Peto R, Boreham J, \& Sutherland I (2004). Mortality in relation to smoking: 50 years' observations on male British doctors. BMJ, 328(7455), 1519. doi: 10.1136/bmj. 38142.554479.AE

Etter JF (2018). Electronic Cigarette: A Longitudinal Study of Regular Vapers. Nicotine Tob Res, 20(8), 912-922. doi: $10.1093 / n t r / n t \times 132$

European Union (2012). Attitudes of European towards tobacco. Special Eurobarometer 385. Retrieved from https://ec.europa.eu/health//sites/health/files/tobacco/docs/ eurobaro_attitudes_towards_tobacco_2012_en.pdf

Foulds J, Veldheer S, Yingst J, Hrabovsky S, Wilson SJ, Nichols TT, \& Eissenberg T (2015). Development of a Questionnaire for Assessing Dependence on Electronic Cigarettes Among a Large Sample of Ex-Smoking E-cigarette Users. Nicotine Tob Res, 17(2), 186-192. doi: $10.1093 /$ ntr/ntu204

Gallus S, Muttarak R, Franchi M, Pacifici R, Colombo P, Boffetta P, Leon ME, \& La Vecchia C (2013). Why do smokers quit? Eur J Cancer Prev, 22(1), 96-101. doi: 10.1097/CEJ. Ob013e3283552da8

Grana R, Benowitz N, \& Glantz SA (2014). E-Cigarettes: a Scientific Review. Circulation, 129(19), 1972-1986. doi: 10.1161/CIRCULATIONAHA.114.007667 
Grant JE, Lust K, Fridberg DJ, King C, \& Samuel R (2019). E-cigarette use (vaping) is associated with illicit drug use, mental health problems, and impulsivity in university students. Am Clin Psychiatry, 31(1), 27-35.

Greenhill R, Dawkins L, Notley C, Finn MD, \& Turner JJD (2016). Adolescent Awareness and Use of Electronic Cigarettes: A Review of Emerging Trends and Findings. J Adolesc Health, 59(6), 612-619. doi: 10.1016/j.jadohealth.2016.08.005

Guignard R, Beck F, Richard JB, Lermenier A, Wilquin JL, \& Nguyen-Thanh V (2015). La consommation de tabac en France en 2014: caractéristiques et évolutions récentes [Tobacco consumption in France in 2014: characteristics and recent trends]. Evolution, 31, 1-10. Retrieved from http://inpes.santepubliquefrance.fr/CFESBases/catalogue/pdf/ 1623.pdf

Hajek P, Etter JF, Benowitz N, Eissenberg T, \& Mc Robbie H (2014). Electronic cigarettes : review of use, content, safety, effects on smokers, and potential for harm and benefit. Addiction, 109(11), 1801-1810. doi: 10.1111/add.12659

Hedman L, Backman H, Stridsman C, Bosson JA, Lundback M, Lindberg A, Ronmark E, \& Ekerljung $L$ (2018). Association of electronic cigarette use with smoking habits, demographic factors, and respiratory symptoms. JAMA Netw Open, 1(3), e180789. doi: $0.1001 /$ jamanetworkopen.2018.0789

Institut national de la statistique et des études économiques [Insee] (2011). Le taux de chômage augmente au troisième trimestre [Unemployment rate rises in the third quarter]. Informations rapides Conjoncture, 294, 1-2. Retrieved from https://www.insee.fr/fr/ statistiques/1562793

Jankowski M, Krzystanek M, Zejda JE, Majek P, Lubanski J, Lawson JA, \& Brozek G (2019). Ecigarette are more addictive than traditional cigarettes- A study in Highly educated young people. Int J Environ Res Public Health, 16(13), 2279. doi: 10.3390/ijerph16132279

Khati I, Menvielle G, Chollet A, Younès N, Metadieu B, \& Melchior M (2015). What distinguishes successful from unsuccessful tobacco smoking cessation? Data from a study of young adults (TEMPO). Prev Med Rep, 2, 679-685. doi: 10.1016/j.pmedr.2015.08.006 
Le Monde (2014). 5 raisons de passer du tabac à la cigarette électronique [5 reasons to switch from tobacco to e-cigarette]. Retrieved from https://www.lemonde.fr/societe/article/ 2014/02/28/vapoter-a-change-ma-vie_4375468_3224.html

Lermenier A, \& Palle C (2014). Résultats de l'enquête ETINCEL-OFDT sur la cigarette électronique: prévalence, comportements d'achat et d'usage, motivations des utilisateurs [Results of ETINCEL-OFDT survey on e-cigarette: prevalence, buying and use behaviour, user motivations]. Note, 2014-01, 1-15. Retrieved from http://www.ofdt.fr/publications/ collections/notes/resultats-de-lenquete-etincel-ofdt-sur-la-cigarette-electroniqueprevalence-comportements-dachat-et-dusage-motivations-des-utili/

Li J, Newcombe R, \& Walton D (2015). The prevalence, correlates and reasons for using electronic cigarettes among New Zealand adults. Addict Behav, 45, 245-251. doi: 10.1016/ j.addbeh.2015.02.006

Liu X, Lugo A, Davoli E, Gorini G, Pacifici R, Fernandez E, \& Gallus S (2019). Electronic cigarettes in Italy: a tool for harm reduction or a gateway to smoking tobacco. Tob Control. doi: 10.1136/tobaccocontrol-2018-054726

Mayorga NA, Garey L, \& Zvolensky MJ (2019). Differences in perceptions of e-cigarettes across daily and non-daily users. Addict Behv, 90, 415-420. doi: 10.1016/j.addbeh.2018.12.004 Melchior M, Caspi A, Milne BJ, Danese A, Poulton R, \& Moffitt TE (2007). Work stress precipitates depression and anxiety in young, working women and men. Psychol Med, 37(8), 1119-1129. doi: $10.1017 / \mathrm{S} 0033291707000414$

U.S. Department of Health and Human Services (2016). E-cigarette use among youth and young adults: a report of the surgeon general. Atlanta, GA: U.S. Department of Health and Human Services, Centers for Disease Control and Prevention, National Center for Chronic Disease Prevention and Health Promotion, Office on Smoking and Health. Retrieved from https://e-cigarettes.surgeongeneral.gov/documents/2016_sgr_full_report_non-508.pdf

Ng M, Freeman MK, Fleming TD, Robinson M, Dwyer-Lindgren L, Thomson B, Wollum A, Sanman E, Wulf S, Lopez AD, Murray CJ, \& Gakidou E (2014). Smoking Prevalence and Cigarette Consumption in 187 Countries, 1980-2012. JAMA, 311(2), 183-192. doi: 10.1001/jama. 2013.284692 
Oakly A, Edwards R, \& Martin G (2019). Prevalence of e-cigarette use from a nationally representative sample in New Zealand. Addict Behav, 98:106024. doi: 10.1016/j.addbeh. 2019.06.013.

Official Journal of the French Republic (2019). Judgment of 30 January 2019 approving the retail prices of tobacco manufactured in France, excluding the overseas departments. NOR: CPAD1903000A. Retrieved from https://www.legifrance.gouv.fr/affichTexte.do? cidTexte=JORFTEXT000038175390\&categorieLien=id

Pasquereau A, Gautier A, Andler R, Guignard R, Richard JB, Nguyen-Thanh V, \& le groupe Baromètre santé 2016 (2017). Tabac et e-cigarette en France : niveaux d'usage d'après les premiers résultats du Baromètre santé 2016 [Smoking and e-cigarettes in France: using levels based on the first results of 2016 Health Barometer]. Bull Epidémiol Hebd, 12, 214-222. Retrieved from http://invs.santepubliquefrance.fr/beh/2017/12/2017_12_1.html

Pasquereau A, Guignard R, Andler R, \& Nguyen-Thanh V (2017). Electronic cigarettes, quit attempts and smoking cessation: a 6-month follow-up. Addiction, 112(9), 1620-1628. doi: $10.1111 /$ add. 13869

Queloz S, \& Etter JF (2019). An online survey of users of tobacco vaporizers, reasons and modes of utilization, perceived advantages and perceives risks. MBC Public Health, 19(1), 642. doi: $10.1186 / \mathrm{s} 12889-019-6957-0$

Redonnet B, Chollet A, Fombonne E, Bowes L, \& Melchior M (2012). Tobacco, alcohol, cannabis and other illegal drug use among young adults: The socio-economical context. Drug Alcohol Depend, 121(3), 231-239. doi: 10.1016/j.drugalcdep.2011.09.002

Reid JL, Rynard VL, Czoli CD, \& Hammond D (2015). Who is using e-cigarettes in Canada? Nationally representative data on the prevalence of e-cigarette use among Canadians. Prev Med, 81, 180-183. doi: 10.1016/j.ypmed.2015.08.019

Rockhill KM, Tong VT, Farr SL, Robbins CL, D’Angelo DV, \& England LJ (2016). Postpartum smoking relapse after quitting during pregnancy: Pregnancy risk assessment monitoring system, 2000-2011. J Womens Health, 25(5), 480-488. doi: 10.1089/jwh.2015.5244

Rutten LJ, Blake KD, Agunwamba AA, Grana RA, Wilson PM, Ebbert JO, Okamoto J, \& Leischow SJ (2015). Use of E-Cigarettes among Current Smokers: Associations among Reasons for Use, 
Quit Intentions, and Current Tobacco Use. Nicotine Tob Res, 17(10), 1228-1234. doi: $10.1093 / \mathrm{ntr} / \mathrm{ntv} 003$

SAS Institute (2013). Base SAS ${ }^{2} 9.4$ Procedures Guide: Statistical Procedures (2nd ed.). Cary: SAS Institute Inc. Retrieved from https://support.sas.com/documentation/cdl/en/procstat/ 66703/PDF/default/procstat.pdf.

Soneji S, Barrington-Trimis JL, Wills TA, Leventhal AM, Unger JB, Gibson LA, Yang J, Primack BA, Andrews JA, Miech RA, Spindle TR, Dick DM, Eissenberg T, Hornik RC, Dang R, \& Sargent JD (2017). Association between initial use of e-cigarette and subesequent cigarette smoking among adolescents and young adults: a systematic rewiew and meta-analysis. JAMA Pediatr, 171 (8), 788-797. doi: 10.1001/jamapediatrics.2017.1488

Spilka S, Le Nezet O, Ngantcha M, \& Beck F (2015). Consommation de tabac et usage de cigarette électronique à 17 ans en France, 2014 [Smoking and e-cigarette use at age 17 in France, 2014]. Bull Epidémiol Hebd, 17-18, 289-296. Retrieved from http:// invs.santepubliquefrance.fr//beh/2015/17-18/2015_17-18_2.html

Tavakol M, \& Dennick R (2011). Making sense of Cronbach's alpha. Int J Med Educ, 2, 53-55. doi: $10.5116 /$ ijme.4dfb.8dfd

Tworek C, Schauer GL, Wu CC, Malarcher AM, Jackson KJ, \& Hoffman AC (2014). Youth tobacco cessation: quitting intentions and past-year quit attempts. Am J Prev Med, 47(2 Suppl 1), S15-27. doi: 10.1016/j.amepre.2014.05.009

van Buuren S (2007). Multiple imputation of discrete and continuous data by fully conditional specification. Stat Methods Med Res, 16(3), 219-242. doi: 10.1177/0962280206074463 World Health Organization [WHO] (2018). Obesity and overweight. Retrieved from https:// www.who.int/news-room/fact-sheets/detail/obesity-and-overweight

Table 1: Participants' characteristics according to e-cigarette use (TEMPO cohort study, 2015, $n=368, \%$, bivariate logistic regression). 


\begin{tabular}{|c|c|c|c|c|c|c|c|c|}
\hline & \multicolumn{4}{|c|}{ Lifetime e-cigarette use } & \multicolumn{4}{|c|}{ Current e-cigarette use } \\
\hline & $\begin{array}{l}\text { Never } \\
\text { users of e- } \\
\text { cigarette } \\
(n=269)\end{array}$ & $\begin{array}{l}\text { lifetime } \\
\text { users of e- } \\
\text { cigarette } \\
(n=99)\end{array}$ & $\begin{array}{c}\mathrm{p}- \\
\text { valu } \\
\mathrm{e}\end{array}$ & $\begin{array}{c}\text { OR } \\
(95 \% \mathrm{Cl})\end{array}$ & $\begin{array}{l}\text { Non- } \\
\text { current } \\
\text { users of } \mathrm{e}- \\
\text { cigarette } \\
(\mathrm{n}=312)\end{array}$ & $\begin{array}{c}\text { Current } \\
\text { users of e- } \\
\text { cigarette } \\
(n=56)\end{array}$ & $\begin{array}{c}\mathrm{p}- \\
\text { valu } \\
\mathrm{e}^{1}\end{array}$ & $\begin{array}{c}\text { OR } \\
(95 \% \mathrm{Cl})\end{array}$ \\
\hline \multicolumn{9}{|l|}{ Sex } \\
\hline M & $33.1 \%$ & $41.4 \%$ & $\begin{array}{c}0.1 \\
4\end{array}$ & 1 & $34.0 \%$ & $42.9 \%$ & $\begin{array}{c}0.2 \\
0\end{array}$ & 1 \\
\hline $\mathrm{F}$ & $66.9 \%$ & $58.6 \%$ & & $\begin{array}{c}0.70 \\
(0.44-1.1 \\
2)\end{array}$ & $66.0 \%$ & $57.1 \%$ & & $\begin{array}{c}0.69 \\
(0.39-1.2 \\
2)\end{array}$ \\
\hline \multicolumn{9}{|l|}{ Age } \\
\hline $\begin{array}{l}23-35 \\
\text { years old }\end{array}$ & $46.1 \%$ & $51.5 \%$ & $\begin{array}{c}0.3 \\
6\end{array}$ & 1 & $46.2 \%$ & $55.4 \%$ & $\begin{array}{c}0.2 \\
0\end{array}$ & 1 \\
\hline $\begin{array}{l}36-41 \\
\text { years old }\end{array}$ & $53.9 \%$ & $48.5 \%$ & & $\begin{array}{c}1.24 \\
(0.78-1.97 \\
)\end{array}$ & $53.8 \%$ & $44.6 \%$ & & $\begin{array}{c}1.45 \\
(0.82-2.56 \\
)\end{array}$ \\
\hline \multicolumn{9}{|l|}{$\begin{array}{l}\text { Living with a } \\
\text { partner }\end{array}$} \\
\hline No & $18.2 \%$ & $29.7 \%$ & $\begin{array}{c}0.0 \\
1\end{array}$ & $\begin{array}{c}1.90 \\
(1.11-3.2 \\
3)\end{array}$ & $19.4 \%$ & $32.1 \%$ & $\begin{array}{c}0.0 \\
4\end{array}$ & $\begin{array}{c}1.97 \\
(1.05-3.7 \\
0)\end{array}$ \\
\hline Yes & $81.8 \%$ & $70.3 \%$ & & 1 & $80.6 \%$ & $67.9 \%$ & & 1 \\
\hline \multicolumn{9}{|l|}{ Parental Status } \\
\hline $\begin{array}{l}\text { No } \\
\text { children }\end{array}$ & $29.1 \%$ & $31.3 \%$ & $\begin{array}{c}0.7 \\
8\end{array}$ & 1 & $28.6 \%$ & $35.7 \%$ & $\begin{array}{c}0.4 \\
1\end{array}$ & 1 \\
\hline $\begin{array}{l}\text { A child } \\
\leq 1 \text { year }\end{array}$ & $20.4 \%$ & $22.2 \%$ & & $\begin{array}{c}1.01 \\
(0.53-1.93 \\
)\end{array}$ & $20.8 \%$ & $21.4 \%$ & & $\begin{array}{c}0.83 \\
(0.38-1.81 \\
)\end{array}$ \\
\hline $\begin{array}{l}\text { A child> } \\
1 \text { year }\end{array}$ & $50.5 \%$ & $46.5 \%$ & & $\begin{array}{c}0.85 \\
(0.50-1.46 \\
)\end{array}$ & $50.6 \%$ & $42.9 \%$ & & $\begin{array}{c}0.68 \\
(0.35-1.29 \\
)\end{array}$ \\
\hline \multicolumn{9}{|l|}{$\begin{array}{l}\text { Negative life } \\
\text { events }\end{array}$} \\
\hline No & $42.5 \%$ & $37.7 \%$ & $\begin{array}{c}0.4 \\
4\end{array}$ & 1 & $41.7 \%$ & $38.8 \%$ & $\begin{array}{c}0.7 \\
1\end{array}$ & 1 \\
\hline Yes & $57.5 \%$ & $62.3 \%$ & & $\begin{array}{c}1.22 \\
(0.74-2.03 \\
)\end{array}$ & $58.3 \%$ & $61.2 \%$ & & $\begin{array}{c}1.13 \\
(0.61-2.10 \\
)\end{array}$ \\
\hline \multicolumn{9}{|l|}{$\begin{array}{l}\text { Physical } \\
\text { violence }\end{array}$} \\
\hline No & $87.9 \%$ & $89.4 \%$ & $\begin{array}{c}0.7 \\
1\end{array}$ & 1 & $88.0 \%$ & $89.8 \%$ & $\begin{array}{c}0.7 \\
3\end{array}$ & 1 \\
\hline Yes & $12.1 \%$ & $10.6 \%$ & & $\begin{array}{c}0.86 \\
(0.39-1.90 \\
)\end{array}$ & $12.0 \%$ & $10.2 \%$ & & $\begin{array}{c}0.84 \\
(0.31-2.26 \\
)\end{array}$ \\
\hline
\end{tabular}




\begin{tabular}{|c|c|c|c|c|c|c|c|c|}
\hline \multicolumn{9}{|l|}{$\begin{array}{l}\text { Psychological } \\
\text { violence }\end{array}$} \\
\hline No & $72.9 \%$ & $74.1 \%$ & $\begin{array}{c}0.8 \\
3\end{array}$ & 1 & $72.5 \%$ & $77.6 \%$ & $\begin{array}{c}0.4 \\
6\end{array}$ & 1 \\
\hline Yes & $27.1 \%$ & $25.9 \%$ & & $\begin{array}{c}0.94 \\
(0.54-1.65 \\
)\end{array}$ & $27.5 \%$ & $22.4 \%$ & & $\begin{array}{c}0.76 \\
(0.37-1.57 \\
)\end{array}$ \\
\hline \multicolumn{9}{|l|}{$\begin{array}{l}\text { Socioeconomic } \\
\text { position }\end{array}$} \\
\hline Low & $31.0 \%$ & $41.7 \%$ & $\begin{array}{c}0.0 \\
6\end{array}$ & $\begin{array}{c}1.59 \\
(0.97-2.6 \\
0)\end{array}$ & $33.3 \%$ & $37.5 \%$ & $\begin{array}{c}0.5 \\
8\end{array}$ & $\begin{array}{c}1.20 \\
(0.65-2.23 \\
)\end{array}$ \\
\hline $\begin{array}{l}\text { Intermed } \\
\text { iate/ } \\
\text { High }\end{array}$ & $69.0 \%$ & $58.3 \%$ & & 1 & $66.7 \%$ & $62.5 \%$ & & 1 \\
\hline \multicolumn{9}{|l|}{$\begin{array}{l}\text { Self-rated } \\
\text { health }\end{array}$} \\
\hline Good & $96.6 \%$ & $98.0 \%$ & $\begin{array}{c}0.7 \\
3\end{array}$ & 1 & $96.8 \%$ & $98.2 \%$ & $\ldots$ & 1 \\
\hline Not good & $3.4 \%$ & $2.0 \%$ & & $\begin{array}{c}0.60 \\
(0.13-2.82 \\
)\end{array}$ & $3.2 \%$ & $1.8 \%$ & & $\begin{array}{c}0.56 \\
(0.07-4.43 \\
)\end{array}$ \\
\hline \multicolumn{9}{|l|}{$\begin{array}{l}\text { Chronic } \\
\text { disease }\end{array}$} \\
\hline No & $78.0 \%$ & $75.8 \%$ & $\begin{array}{c}0.6 \\
5\end{array}$ & 1 & $77.5 \%$ & $76.8 \%$ & $\begin{array}{c}0.9 \\
1\end{array}$ & 1 \\
\hline Yes & $22.0 \%$ & $24.2 \%$ & & $\begin{array}{c}1.13 \\
(0.66-1.95 \\
)\end{array}$ & $22.5 \%$ & $23.2 \%$ & & $\begin{array}{c}1.04 \\
(0.53-2.05 \\
)\end{array}$ \\
\hline \multicolumn{9}{|l|}{ Depression } \\
\hline No & $87.0 \%$ & $80.8 \%$ & $\begin{array}{c}0.1 \\
4\end{array}$ & 1 & $86.5 \%$ & $78.6 \%$ & $\begin{array}{c}0.1 \\
2\end{array}$ & 1 \\
\hline Yes & $13.0 \%$ & $19.2 \%$ & & $\begin{array}{c}1.58 \\
(0.86-2.9 \\
2)\end{array}$ & $13.5 \%$ & $21.4 \%$ & & $\begin{array}{c}1.75 \\
(0.86-3.5 \\
9)\end{array}$ \\
\hline \multicolumn{9}{|l|}{ Migraine } \\
\hline No & $88.5 \%$ & $84.8 \%$ & $\begin{array}{c}0.3 \\
5\end{array}$ & 1 & $88.5 \%$ & $82.1 \%$ & $\begin{array}{c}0.1 \\
9\end{array}$ & 1 \\
\hline Yes & $11.5 \%$ & $15.2 \%$ & & $\begin{array}{c}1.37 \\
(0.70-2.65 \\
)\end{array}$ & $11.5 \%$ & $17.9 \%$ & & $\begin{array}{c}1.67 \\
(0.77-3.5 \\
9)\end{array}$ \\
\hline \multicolumn{9}{|l|}{ Asthma } \\
\hline No & $91.8 \%$ & $82.8 \%$ & $\begin{array}{c}0.0 \\
1\end{array}$ & 1 & $90.4 \%$ & $83.9 \%$ & $\begin{array}{c}0.1 \\
5\end{array}$ & 1 \\
\hline Yes & $8.2 \%$ & $17.2 \%$ & & $\begin{array}{c}2.32 \\
(1.17-4.5 \\
8)\end{array}$ & $9.6 \%$ & $16.1 \%$ & & $\begin{array}{c}1.80 \\
(0.80-4.0 \\
3)\end{array}$ \\
\hline
\end{tabular}




\begin{tabular}{|c|c|c|c|c|c|c|c|c|}
\hline \multicolumn{9}{|l|}{$\begin{array}{l}\text { Cardiovascular } \\
\text { disease }\end{array}$} \\
\hline No & $92.2 \%$ & $91.9 \%$ & $\begin{array}{c}0.9 \\
4\end{array}$ & 1 & $92.0 \%$ & $92.9 \%$ & $\ldots$ & 1 \\
\hline Yes & $7.8 \%$ & $8.1 \%$ & & $\begin{array}{c}1.03 \\
(0.44-2.42 \\
)\end{array}$ & $8.0 \%$ & $7.1 \%$ & & $\begin{array}{c}0.88 \\
(0.29-2.63 \\
)\end{array}$ \\
\hline \multicolumn{9}{|l|}{ Cancer } \\
\hline No & $97.0 \%$ & $98.0 \%$ & $\begin{array}{c}1.0 \\
0\end{array}$ & 1 & $97.1 \%$ & $98.2 \%$ & $\ldots$ & 1 \\
\hline Yes & $3.0 \%$ & $2.0 \%$ & & $\begin{array}{c}0.67 \\
(0.14-3.21 \\
)\end{array}$ & $2.9 \%$ & $1.8 \%$ & & $\begin{array}{c}0.61 \\
(0.08-4.91 \\
)\end{array}$ \\
\hline
\end{tabular}




\begin{tabular}{|c|c|c|c|c|c|c|c|c|}
\hline \multicolumn{9}{|l|}{ Diabetes } \\
\hline No & $98.1 \%$ & $97.0 \%$ & $\begin{array}{c}0.4 \\
5\end{array}$ & 1 & $97.8 \%$ & $98.2 \%$ & $\ldots$ & 1 \\
\hline Yes & $1.9 \%$ & $3.0 \%$ & & $\begin{array}{c}1.64 \\
(0.39-7.01 \\
)\end{array}$ & $2.2 \%$ & $1.8 \%$ & & $\begin{array}{c}0.79 \\
(0.10-6.55 \\
)\end{array}$ \\
\hline \multicolumn{9}{|l|}{ Obesity } \\
\hline No & $93.7 \%$ & $87.9 \%$ & $\begin{array}{c}0.0 \\
7\end{array}$ & 1 & $92.9 \%$ & $87.5 \%$ & $\begin{array}{c}0.1 \\
6\end{array}$ & 1 \\
\hline Yes & $6.3 \%$ & $12.1 \%$ & & $\begin{array}{c}2.07 \\
(0.95-4.5 \\
1)\end{array}$ & $7.1 \%$ & $12.5 \%$ & & $\begin{array}{c}1.92 \\
(0.78-4.7 \\
5)\end{array}$ \\
\hline \multicolumn{9}{|l|}{$\begin{array}{l}\text { Chronic } \\
\text { digestive } \\
\text { disease }\end{array}$} \\
\hline No & $93.7 \%$ & $93.9 \%$ & $\begin{array}{c}0.9 \\
2\end{array}$ & 1 & $93.6 \%$ & $94.6 \%$ & $\ldots$ & 1 \\
\hline Yes & $6.3 \%$ & $6.1 \%$ & & $\begin{array}{c}0.95 \\
(0.37-2.49 \\
)\end{array}$ & $6.4 \%$ & $5.4 \%$ & & $\begin{array}{c}0.82 \\
(0.24-2.87 \\
)\end{array}$ \\
\hline \multicolumn{9}{|l|}{$\begin{array}{l}\text { Musculoskeleta } \\
\text { I disorder }\end{array}$} \\
\hline No & $69.0 \%$ & $69.7 \%$ & $\begin{array}{c}0.9 \\
0\end{array}$ & 1 & $68.2 \%$ & $75.0 \%$ & $\begin{array}{c}0.3 \\
1\end{array}$ & 1 \\
\hline Yes & $31.0 \%$ & $30.3 \%$ & & $\begin{array}{c}0.97 \\
(0.59-1.60 \\
)\end{array}$ & $31.8 \%$ & $25.0 \%$ & & $\begin{array}{c}0.71 \\
(0.37-1.37 \\
)\end{array}$ \\
\hline \multicolumn{9}{|l|}{$\begin{array}{l}\text { Regular } \\
\text { smoking }\end{array}$} \\
\hline $\begin{array}{l}\text { Neither } \\
\text { in } 2011 \\
\text { nor in } \\
2015\end{array}$ & $46.5 \%$ & $8.2 \%$ & $\begin{array}{l}<0 \\
001\end{array}$ & 1 & $40.7 \%$ & $11.1 \%$ & $\begin{array}{l}<0 \\
001\end{array}$ & 1 \\
\hline $\begin{array}{l}\text { In } 2011 \\
\text { and } 2015\end{array}$ & $30.6 \%$ & $64.8 \%$ & & $\begin{array}{c}12.10 \\
(5.29-27 \\
65)\end{array}$ & $38.0 \%$ & $50.2 \%$ & & $\begin{array}{c}4.90 \\
(1.82-13 \\
17)\end{array}$ \\
\hline $\begin{array}{l}\text { In } 2011 \\
\text { only }\end{array}$ & $9.4 \%$ & $14.7 \%$ & & $\begin{array}{c}8.93 \\
(3.31-24 \\
12)\end{array}$ & $9.6 \%$ & $17.9 \%$ & & $\begin{array}{c}6.92 \\
(2.20-21 \\
78)\end{array}$ \\
\hline $\begin{array}{l}\text { In } 2015 \\
\text { only }\end{array}$ & $13.5 \%$ & $12.2 \%$ & & $\begin{array}{c}5.19 \\
(1.89-14 \\
24)\end{array}$ & $11.7 \%$ & $20.9 \%$ & & $\begin{array}{c}6.61 \\
(2.20-19 \\
87)\end{array}$ \\
\hline \multicolumn{9}{|l|}{ Alcohol abuse } \\
\hline No & $80.6 \%$ & $79.4 \%$ & $\begin{array}{c}0.8 \\
7\end{array}$ & 1 & $80.9 \%$ & $76.6 \%$ & $\begin{array}{c}0.4 \\
9\end{array}$ & 1 \\
\hline Yes & $19.4 \%$ & $20.6 \%$ & & $\begin{array}{c}1.08 \\
(0.58-2.00 \\
)\end{array}$ & $19.1 \%$ & $23.4 \%$ & & $\begin{array}{c}1.29 \\
(0.64-2.63 \\
)\end{array}$ \\
\hline
\end{tabular}




\begin{tabular}{|c|c|c|c|c|c|c|c|c|}
\hline Cannabis & & & & & & & & \\
\hline No & $75.8 \%$ & $58.6 \%$ & $\begin{array}{c}0.0 \\
02\end{array}$ & 1 & $73.2 \%$ & $59.8 \%$ & $\begin{array}{c}0.0 \\
6\end{array}$ & 1 \\
\hline Yes & $24.2 \%$ & $41.4 \%$ & & $\begin{array}{c}2.21 \\
(1.32-3.7 \\
1)\end{array}$ & $26.8 \%$ & $40.2 \%$ & & $\begin{array}{c}1.83 \\
(0.98-3.4 \\
2)\end{array}$ \\
\hline
\end{tabular}




\begin{tabular}{|c|c|c|c|c|c|c|c|c|}
\hline \multicolumn{9}{|l|}{$\begin{array}{l}\text { Perception of } \\
\text { e-cigarettes }\end{array}$} \\
\hline $\begin{array}{l}\text { Non } \\
\text { positive }\end{array}$ & $77.4 \%$ & $49.5 \%$ & $\begin{array}{l}<0 . \\
001\end{array}$ & 1 & $74.8 \%$ & $42.9 \%$ & $\begin{array}{l}<0 \\
001\end{array}$ & 1 \\
\hline Positive & $22.6 \%$ & $50.5 \%$ & & $\begin{array}{c}3.50 \\
(2.15-5.7 \\
1)\end{array}$ & $25.2 \%$ & $57.1 \%$ & & $\begin{array}{c}3.95 \\
(2.19-7.1 \\
2)\end{array}$ \\
\hline
\end{tabular}


Table 2: Factors associated with lifetime or current e-cigarette use (TEMPO cohort study, 2015, $n=368$, multivariate logistic regression). 


\begin{tabular}{|c|c|c|}
\hline & $\begin{array}{l}\text { Lifetime e-cigarette use } \\
\text { OR }(95 \% \mathrm{Cl})\end{array}$ & $\begin{array}{c}\text { Current e-cigarette use } \\
\text { OR }(95 \% \mathrm{Cl})\end{array}$ \\
\hline \multicolumn{3}{|l|}{ Sex } \\
\hline M & 1 & 1 \\
\hline $\mathrm{F}$ & $0.96(0.53-1.74)$ & $0.85(0.43-1.66)$ \\
\hline \multicolumn{3}{|l|}{ Age } \\
\hline 23-35 years old & 1 & 1 \\
\hline $36-41$ years old & $1.00(0.56-1.80)$ & $0.71(0.36-1.38)$ \\
\hline \multicolumn{3}{|l|}{ Living with a partner } \\
\hline No & $1.26(0.65-2.45)$ & $1.35(0.63-2.87)$ \\
\hline Yes & 1 & 1 \\
\hline \multicolumn{3}{|l|}{ Socioeconomic position } \\
\hline Low & $2.20(1.17-4.15)$ & $1.44(0.70-2.96)$ \\
\hline Intermediate/High & 1 & 1 \\
\hline \multicolumn{3}{|l|}{ Depression } \\
\hline No & 1 & 1 \\
\hline Yes & $0.95(0.44-2.03)$ & $1.08(0.47-2.49)$ \\
\hline \multicolumn{3}{|l|}{ Migraine } \\
\hline No & 1 & 1 \\
\hline Yes & $1.77(0.79-3.97)$ & $2.18(0.90-5.27)$ \\
\hline \multicolumn{3}{|l|}{ Asthma } \\
\hline No & 1 & 1 \\
\hline Yes & $2.14(0.94-4.86)$ & $1.80(0.72-4.49)$ \\
\hline \multicolumn{3}{|l|}{ Obesity } \\
\hline No & 1 & 1 \\
\hline Yes & $2.54(0.94-6.87)$ & $2.77(0.95-8.03)$ \\
\hline \multicolumn{3}{|l|}{ Regular smoking } \\
\hline $\begin{array}{l}\text { Neither in } 2011 \text { nor in } \\
2015 \text { (former smokers) }\end{array}$ & 1 & 1 \\
\hline In 2011 and 2015 & $13.06(5.24-32.58)$ & $3.91(1.25-12.21)$ \\
\hline In 2011 only & $10.84(3.59-32.69)$ & $6.78(1.93-23.74)$ \\
\hline In 2015 only & $7.32(2.48-21.62)$ & $8.50(2.57-28.12)$ \\
\hline \multicolumn{3}{|l|}{ Cannabis use } \\
\hline No & 1 & 1 \\
\hline Yes & $1.25(0.65-2.39)$ & $1.33(0.61-2.90)$ \\
\hline \multicolumn{3}{|l|}{ Perception of e-cigarettes } \\
\hline Non positive & 1 & 1 \\
\hline
\end{tabular}


Supplementary material:

Figure 1 : Flowchart 


\section{Gazel cohort (1989)}

Self-administered questionnaire sent by post, $N=20,624$

Random sample families with youths aged 4-16 years, $N=4,335$

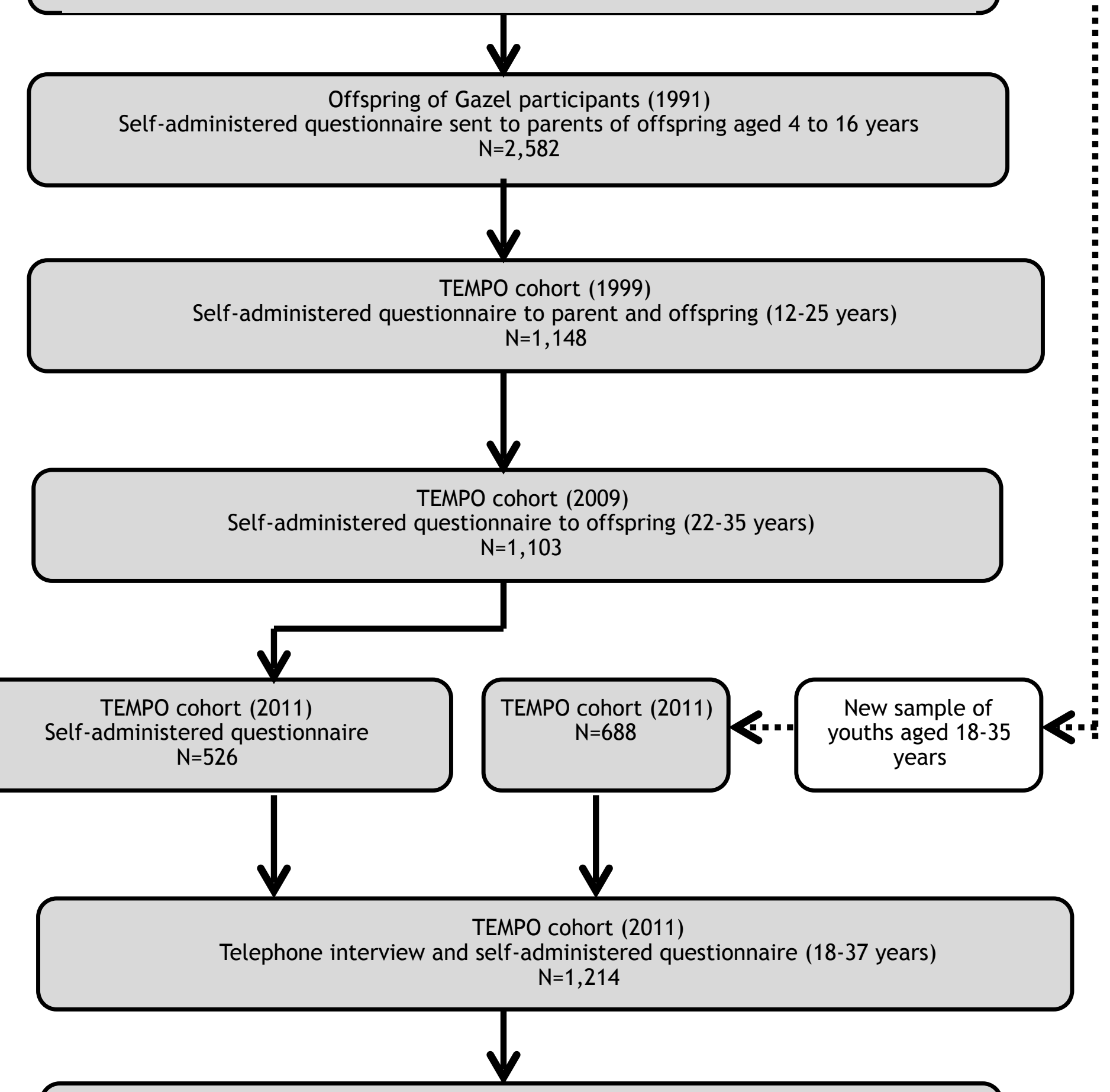

TEMPO cohort (2015)

Self-administered questionnaire (22-41 years)

$\mathrm{N}=786$

TEMPO cohort (2015)

Smokers and former smokers who provided e-cigarette data $\mathrm{N}=368$ 
Table 1: Participants' characteristics according to e-cigarette use (TEMPO cohort study, 2015, n=368, \%, bivariate logistic regression). 


\begin{tabular}{|c|c|c|c|c|c|c|c|c|}
\hline & \multicolumn{4}{|c|}{ Lifetime e-cigarette use } & \multicolumn{4}{|c|}{ Current e-cigarette use } \\
\hline & $\begin{array}{c}\text { Never users of } \\
\text { e-cigarette } \\
(n=269)\end{array}$ & $\begin{array}{l}\text { lifetime users of } \\
\text { e-cigarette } \\
(n=99)\end{array}$ & $\begin{array}{c}\mathrm{p}- \\
\text { value }\end{array}$ & $\begin{array}{c}\text { OR } \\
(95 \% \mathrm{Cl})\end{array}$ & $\begin{array}{l}\text { Non-current } \\
\text { users of e- } \\
\text { cigarette } \\
(n=312)\end{array}$ & $\begin{array}{l}\text { Current users of } \\
\text { e-cigarette } \\
\qquad(n=56)\end{array}$ & $\begin{array}{c}\text { p- } \\
\text { value }\end{array}$ & $\begin{array}{c}\text { OR } \\
(95 \% \mathrm{Cl})\end{array}$ \\
\hline \multicolumn{9}{|l|}{ Sex } \\
\hline$M$ & $33.1 \%$ & $41.4 \%$ & 0.14 & 1 & $34.0 \%$ & $42.9 \%$ & 0.20 & 1 \\
\hline $\mathrm{F}$ & $66.9 \%$ & $58.6 \%$ & & $\begin{array}{c}0.70 \\
(0.44-1.12)\end{array}$ & $66.0 \%$ & $57.1 \%$ & & $\begin{array}{c}0.69 \\
(0.39-1.22)\end{array}$ \\
\hline \multicolumn{9}{|l|}{ Age } \\
\hline 23-35 years old & $46.1 \%$ & $51.5 \%$ & 0.36 & 1 & $46.2 \%$ & $55.4 \%$ & 0.20 & 1 \\
\hline $36-41$ years old & $53.9 \%$ & $48.5 \%$ & & $\begin{array}{c}1.24 \\
(0.78-1.97)\end{array}$ & $53.8 \%$ & $44.6 \%$ & & $\begin{array}{c}1.45 \\
(0.82-2.56)\end{array}$ \\
\hline \multicolumn{9}{|l|}{ Living with a partner } \\
\hline No & $18.2 \%$ & $29.7 \%$ & 0.01 & $\begin{array}{c}1.90 \\
(1.11-3.23)\end{array}$ & $19.4 \%$ & $32.1 \%$ & 0.04 & $\begin{array}{c}1.97 \\
(1.05-3.70)\end{array}$ \\
\hline Yes & $81.8 \%$ & $70.3 \%$ & & 1 & $80.6 \%$ & $67.9 \%$ & & 1 \\
\hline \multicolumn{9}{|l|}{ Parental Status } \\
\hline No children & $29.1 \%$ & $31.3 \%$ & 0.78 & 1 & $28.6 \%$ & $35.7 \%$ & 0.41 & 1 \\
\hline A child $\leq 1$ year & $20.4 \%$ & $22.2 \%$ & & $\begin{array}{c}1.01 \\
(0.53-1.93)\end{array}$ & $20.8 \%$ & $21.4 \%$ & & $\begin{array}{c}0.83 \\
(0.38-1.81)\end{array}$ \\
\hline A child> 1 year & $50.5 \%$ & $46.5 \%$ & & $\begin{array}{c}0.85 \\
(0.50-1.46)\end{array}$ & $50.6 \%$ & $42.9 \%$ & & $\begin{array}{c}0.68 \\
(0.35-1.29)\end{array}$ \\
\hline \multicolumn{9}{|l|}{ Negative life events } \\
\hline No & $42.5 \%$ & $37.7 \%$ & 0.44 & 1 & $41.7 \%$ & $38.8 \%$ & 0.71 & 1 \\
\hline Yes & $57.5 \%$ & $62.3 \%$ & & $\begin{array}{c}1.22 \\
(0.74-2.03)\end{array}$ & $58.3 \%$ & $61.2 \%$ & & $\begin{array}{c}1.13 \\
(0.61-2.10)\end{array}$ \\
\hline
\end{tabular}




\begin{tabular}{|c|c|c|c|c|c|c|c|c|}
\hline No & $87.9 \%$ & $89.4 \%$ & 0.71 & 1 & $88.0 \%$ & $89.8 \%$ & 0.73 & 1 \\
\hline Yes & $12.1 \%$ & $10.6 \%$ & & $\begin{array}{c}0.86 \\
(0.39-1.90)\end{array}$ & $12.0 \%$ & $10.2 \%$ & & $\begin{array}{c}0.84 \\
(0.31-2.26)\end{array}$ \\
\hline \multicolumn{9}{|l|}{ Psychological violence } \\
\hline No & $72.9 \%$ & $74.1 \%$ & 0.83 & 1 & $72.5 \%$ & $77.6 \%$ & 0.46 & 1 \\
\hline Yes & $27.1 \%$ & $25.9 \%$ & & $\begin{array}{c}0.94 \\
(0.54-1.65)\end{array}$ & $27.5 \%$ & $22.4 \%$ & & $\begin{array}{c}0.76 \\
(0.37-1.57)\end{array}$ \\
\hline \multicolumn{9}{|c|}{ Socioeconomic position } \\
\hline Low & $31.0 \%$ & $41.7 \%$ & 0.06 & $\begin{array}{c}1.59 \\
(0.97-2.60)\end{array}$ & $33.3 \%$ & $37.5 \%$ & 0.58 & $\begin{array}{c}1.20 \\
(0.65-2.23)\end{array}$ \\
\hline $\begin{array}{l}\text { Intermediate/ } \\
\text { High }\end{array}$ & $69.0 \%$ & $58.3 \%$ & & 1 & $66.7 \%$ & $62.5 \%$ & & 1 \\
\hline \multicolumn{9}{|l|}{ Self-rated health } \\
\hline Good & $96.6 \%$ & $98.0 \%$ & 0.73 & 1 & $96.8 \%$ & $98.2 \%$ & $\ldots$ & 1 \\
\hline Not good & $3.4 \%$ & $2.0 \%$ & & $\begin{array}{c}0.60 \\
(0.13-2.82)\end{array}$ & $3.2 \%$ & $1.8 \%$ & & $\begin{array}{c}0.56 \\
(0.07-4.43)\end{array}$ \\
\hline \multicolumn{9}{|l|}{ Chronic disease } \\
\hline No & $78.0 \%$ & $75.8 \%$ & 0.65 & 1 & $77.5 \%$ & $76.8 \%$ & 0.91 & 1 \\
\hline Yes & $22.0 \%$ & $24.2 \%$ & & $\begin{array}{c}1.13 \\
(0.66-1.95)\end{array}$ & $22.5 \%$ & $23.2 \%$ & & $\begin{array}{c}1.04 \\
(0.53-2.05)\end{array}$ \\
\hline \multicolumn{9}{|l|}{ Depression } \\
\hline No & $87.0 \%$ & $80.8 \%$ & 0.14 & 1 & $86.5 \%$ & $78.6 \%$ & 0.12 & 1 \\
\hline Yes & $13.0 \%$ & $19.2 \%$ & & $\begin{array}{c}1.58 \\
(0.86-2.92)\end{array}$ & $13.5 \%$ & $21.4 \%$ & & $\begin{array}{c}1.75 \\
(0.86-3.59)\end{array}$ \\
\hline \multicolumn{9}{|l|}{ Migraine } \\
\hline No & $88.5 \%$ & $84.8 \%$ & 0.35 & 1 & $88.5 \%$ & $82.1 \%$ & 0.19 & 1 \\
\hline
\end{tabular}




\begin{tabular}{|c|c|c|c|c|c|c|c|c|}
\hline Yes & $11.5 \%$ & $15.2 \%$ & & $\begin{array}{c}1.37 \\
(0.70-2.65)\end{array}$ & $11.5 \%$ & $17.9 \%$ & & $\begin{array}{c}1.67 \\
(0.77-3.59)\end{array}$ \\
\hline \multicolumn{9}{|l|}{ Asthma } \\
\hline No & $91.8 \%$ & $82.8 \%$ & 0.01 & 1 & $90.4 \%$ & $83.9 \%$ & 0.15 & 1 \\
\hline Yes & $8.2 \%$ & $17.2 \%$ & & $\begin{array}{c}2.32 \\
(1.17-4.58)\end{array}$ & $9.6 \%$ & $16.1 \%$ & & $\begin{array}{c}1.80 \\
(0.80-4.03)\end{array}$ \\
\hline \multicolumn{9}{|c|}{ Cardiovascular disease } \\
\hline No & $92.2 \%$ & $91.9 \%$ & 0.94 & 1 & $92.0 \%$ & $92.9 \%$ & $\ldots$ & 1 \\
\hline Yes & $7.8 \%$ & $8.1 \%$ & & $\begin{array}{c}1.03 \\
(0.44-2.42)\end{array}$ & $8.0 \%$ & $7.1 \%$ & & $\begin{array}{c}0.88 \\
(0.29-2.63)\end{array}$ \\
\hline \multicolumn{9}{|l|}{ Cancer } \\
\hline No & $97.0 \%$ & $98.0 \%$ & 1.00 & 1 & $97.1 \%$ & $98.2 \%$ & $\cdots$ & 1 \\
\hline Yes & $3.0 \%$ & $2.0 \%$ & & $\begin{array}{c}0.67 \\
(0.14-3.21)\end{array}$ & $2.9 \%$ & $1.8 \%$ & & $\begin{array}{c}0.61 \\
(0.08-4.91)\end{array}$ \\
\hline
\end{tabular}




\begin{tabular}{|c|c|c|c|c|c|c|c|c|}
\hline \multicolumn{9}{|l|}{ Diabetes } \\
\hline No & $98.1 \%$ & $97.0 \%$ & 0.45 & 1 & $97.8 \%$ & $98.2 \%$ & $\ldots$ & 1 \\
\hline Yes & $1.9 \%$ & $3.0 \%$ & & $\begin{array}{c}1.64 \\
(0.39-7.01)\end{array}$ & $2.2 \%$ & $1.8 \%$ & & $\begin{array}{c}0.79 \\
(0.10-6.55)\end{array}$ \\
\hline \multicolumn{9}{|l|}{ Obesity } \\
\hline No & $93.7 \%$ & $87.9 \%$ & 0.07 & 1 & $92.9 \%$ & $87.5 \%$ & 0.16 & 1 \\
\hline Yes & $6.3 \%$ & $12.1 \%$ & & $\begin{array}{c}2.07 \\
(0.95-4.51)\end{array}$ & $7.1 \%$ & $12.5 \%$ & & $\begin{array}{c}1.92 \\
(0.78-4.75)\end{array}$ \\
\hline \multicolumn{9}{|l|}{$\begin{array}{l}\text { Chronic digestive } \\
\text { disease }\end{array}$} \\
\hline No & $93.7 \%$ & $93.9 \%$ & 0.92 & 1 & $93.6 \%$ & $94.6 \%$ & $\ldots$ & 1 \\
\hline Yes & $6.3 \%$ & $6.1 \%$ & & $\begin{array}{c}0.95 \\
(0.37-2.49)\end{array}$ & $6.4 \%$ & $5.4 \%$ & & $\begin{array}{c}0.82 \\
(0.24-2.87)\end{array}$ \\
\hline \multicolumn{9}{|l|}{$\begin{array}{l}\text { Musculoskeletal } \\
\text { disorder }\end{array}$} \\
\hline No & $69.0 \%$ & $69.7 \%$ & 0.90 & 1 & $68.2 \%$ & $75.0 \%$ & 0.31 & 1 \\
\hline Yes & $31.0 \%$ & $30.3 \%$ & & $\begin{array}{c}0.97 \\
(0.59-1.60)\end{array}$ & $31.8 \%$ & $25.0 \%$ & & $\begin{array}{c}0.71 \\
(0.37-1.37)\end{array}$ \\
\hline \multicolumn{9}{|l|}{ Regular smoking } \\
\hline $\begin{array}{l}\text { Neither in } 2011 \\
\text { nor in } 2015 \\
\text { (former } \\
\text { smokers) }\end{array}$ & $46.5 \%$ & $8.2 \%$ & $<0.001$ & 1 & $40.7 \%$ & $11.1 \%$ & $<0.001$ & 1 \\
\hline In 2011 and 2015 & $30.6 \%$ & $64.8 \%$ & & $\begin{array}{c}12.10 \\
(5.29-27.65)\end{array}$ & $38.0 \%$ & $50.2 \%$ & & $\begin{array}{c}4.90 \\
(1.82-13.17)\end{array}$ \\
\hline In 2011 only & $9.4 \%$ & $14.7 \%$ & & $\begin{array}{c}8.93 \\
(3.31-24.12)\end{array}$ & $9.6 \%$ & $17.9 \%$ & & $\begin{array}{c}6.92 \\
(2.20-21.78)\end{array}$ \\
\hline In 2015 only & $13.5 \%$ & $12.2 \%$ & & $\begin{array}{c}5.19 \\
(1.89-14.24)\end{array}$ & $11.7 \%$ & $20.9 \%$ & & $\begin{array}{c}6.61 \\
(2.20-19.87)\end{array}$ \\
\hline
\end{tabular}




\begin{tabular}{|c|c|c|c|c|c|c|c|c|}
\hline \multicolumn{9}{|c|}{ Alcohol abuse } \\
\hline No & $80.6 \%$ & $79.4 \%$ & 0.87 & 1 & $80.9 \%$ & $76.6 \%$ & 0.49 & 1 \\
\hline Yes & $19.4 \%$ & $20.6 \%$ & & $\begin{array}{c}1.08 \\
(0.58-2.00)\end{array}$ & $19.1 \%$ & $23.4 \%$ & & $\begin{array}{c}1.29 \\
(0.64-2.63)\end{array}$ \\
\hline \multicolumn{9}{|c|}{ Cannabis use } \\
\hline No & $75.8 \%$ & $58.6 \%$ & 0.002 & 1 & $73.2 \%$ & $59.8 \%$ & 0.06 & 1 \\
\hline Yes & $24.2 \%$ & $41.4 \%$ & & $\begin{array}{c}2.21 \\
(1.32-3.71)\end{array}$ & $26.8 \%$ & $40.2 \%$ & & $\begin{array}{c}1.83 \\
(0.98-3.42)\end{array}$ \\
\hline
\end{tabular}


Perception of e-

cigarettes

Non positive

$77.4 \%$

$49.5 \%$

$<0.001$

$74.8 \%$

$42.9 \%$

$<0.001$

Positive

$22.6 \%$

$50.5 \%$

3.50

(2.15-5.71)

$25.2 \%$

$57.1 \%$

3.95

(2.19-7.12) 
Table 2: Factors associated with lifetime or current e-cigarette use (TEMPO cohort study, 2015, n=368, multivariate logistic regression). 


\begin{tabular}{|c|c|c|}
\hline & $\begin{array}{c}\text { Lifetime e-cigarette use } \\
\text { OR }(95 \% \mathrm{Cl})\end{array}$ & $\begin{array}{c}\text { Current e-cigarette use } \\
\text { OR }(95 \% \mathrm{Cl})\end{array}$ \\
\hline \multicolumn{3}{|l|}{ Sex } \\
\hline M & 1 & 1 \\
\hline $\mathrm{F}$ & $0.96(0.53-1.74)$ & $0.85(0.43-1.66)$ \\
\hline \multicolumn{3}{|l|}{ Age } \\
\hline \multicolumn{3}{|l|}{ Living with a partner } \\
\hline No & $1.26(0.65-2.45)$ & $1.35(0.63-2.87)$ \\
\hline Yes & 1 & 1 \\
\hline \multicolumn{3}{|l|}{ Socioeconomic position } \\
\hline No & 1 & 1 \\
\hline Yes & $0.95(0.44-2.03)$ & $1.08(0.47-2.49)$ \\
\hline \multicolumn{3}{|l|}{ Migraine } \\
\hline No & 1 & 1 \\
\hline Yes & $1.77(0.79-3.97)$ & $2.18(0.90-5.27)$ \\
\hline \multicolumn{3}{|l|}{ Asthma } \\
\hline No & 1 & 1 \\
\hline Yes & $2.14(0.94-4.86)$ & $1.80(0.72-4.49)$ \\
\hline Obesity & & \\
\hline
\end{tabular}




\begin{tabular}{|c|c|c|}
\hline No & 1 & 1 \\
\hline Yes & $2.54(0.94-6.87)$ & $2.77(0.95-8.03)$ \\
\hline \multicolumn{3}{|l|}{ Regular smoking } \\
\hline $\begin{array}{l}\text { Neither in } 2011 \text { nor in } 2015 \text { (former } \\
\text { smokers) }\end{array}$ & 1 & 1 \\
\hline In 2011 and 2015 & $13.06(5.24-32.58)$ & $3.91(1.25-12.21)$ \\
\hline In 2011 only & $10.84(3.59-32.69)$ & $6.78(1.93-23.74)$ \\
\hline In 2015 only & $7.32(2.48-21.62)$ & $8.50(2.57-28.12)$ \\
\hline \multicolumn{3}{|l|}{ Cannabis use } \\
\hline No & 1 & 1 \\
\hline Yes & $1.25(0.65-2.39)$ & $1.33(0.61-2.90)$ \\
\hline \multicolumn{3}{|l|}{ Perception of e-cigarettes } \\
\hline Non positive & 1 & 1 \\
\hline Positive & $4.43(2.44-8.05)$ & $4.38(2.28-8.40)$ \\
\hline
\end{tabular}

